\title{
Exposure of cod Gadus morhua to resuspended sediment: an experimental study of the impact of bottom trawling
}

\author{
Odd-Børre Humborstad $^{1}$, Terje Jørgensen ${ }^{1, *}{ }^{,}$, Sindre Grotmol $^{2}$ \\ ${ }^{1}$ Responsible Fish Capture Research Group, Institute of Marine Research, PO Box 1870 Nordnes, 5817 Bergen, Norway \\ ${ }^{2}$ Department of Biology, University of Bergen, Allégt. 41, 5007 Bergen, Norway
}

\begin{abstract}
Bottom trawling activities resuspend large amounts of sediment and may be the main agent of sediment transportation in some areas. During periods of intensive fishing by large trawler fleets the high-turbidity environmental conditions they create may become semi-permanent. Little is known about the potential effects of this resuspended sediment on the survival and physiology of marine fish. We carried out a worst-case-scenario simulation whereby groups of cod Gadus morhua were exposed to the highest reported mud concentration behind trawls $\left(550 \mathrm{mg} \mathrm{l}^{-1}\right)$ for periods of $24 \mathrm{~h}, 5 \mathrm{~d}$ and $10 \mathrm{~d}$. No mortality was observed in any of the experimental groups. Histological analyses of gill lamellae of fish exposed to mud suspension for $24 \mathrm{~h}$ showed acute pathological changes in the form of multifocal degenerative lesions. After $5 \mathrm{~d}$ exposure, adaptive changes to cope with the turbid environment were observed. These comprised hypertrophy and hyperplasia of the gill epithelium and became more marked and widespread after $10 \mathrm{~d}$ exposure. The gill lesions observed were similar to those reported in other species exposed to a turbid environment and were in those cases reversible. Analyses of blood plasma cortisol levels showed higher values for fish in the $5 \mathrm{~d}$ exposure group than for fish in the $1 \mathrm{~d}$ exposure group. No other between-group differences were significant. The within-group variation was high in all groups but especially in the $10 \mathrm{~d}$ exposure group.
\end{abstract}

KEY WORDS: Sediment exposure $\cdot$ Resuspended sediment $\cdot$ Trawling impact · Atlantic cod

\section{INTRODUCTION}

Underwater observations of bottom trawls have shown that the ground gear and trawl doors may resuspend bottom sediment, producing highly visible turbid clouds that help to herd fish into the net (Main \& Sangster 1981, Wardle 1983). Trawling can resuspend sediment up to a height of $10 \mathrm{~m}$ above the bottom (Churchill 1989) and may be the main agent of sediment transport in certain areas. While much of the suspended sediment settles within a few hours due to gravity and flocculation, $\sim 10$ to $30 \%$ of the initial load may remain in suspension for several days (Durrieu de Madron et al. 2005). Near bottom sediment concentrations have been reported to be as high as several hundred $\mathrm{mg} \mathrm{l}^{-1}$ (Schubel et al. 1979, Schoellhamer 1996). Calculations for the Middle Atlantic Bight (Churchill
1989) and the Kattegat (Floderus \& Pihl 1990) have indicated that trawling is a more important resuspension agent than wind waves.

Studies of the potential ecological consequences of trawl resuspension have been limited to the effects on sediment biota (Kaiser et al. 2002) (for reviews see also Dayton et al. 1995, Jennings \& Kaiser 1998, Collie et al. 2000). It has been hypothesized that physical alteration of the sediment due to trawling (e.g. Schwinghamer et al. 1998) might alter the affinity of the habitat for benthos (Jones 1992, Smith et al. 2000) and have an impact on biogeochemical processes (Pilskaln et al. 1998, Duplisea et al. 2002, Kaiser et al. 2002).

Estuarine and freshwater species, and especially salmonids, have been extensively studied in terms of the impacts of pulses of high turbidity caused by flooding, erosion, pollution from land run-off, dredging 
activities and aquaculture (Bruton 1985, Newcombe \& MacDonald 1991, Folmar 1993, Newcombe \& Jensen 1996, Wilber \& Clarke 2001). The increased turbidity has consequences for fish that range from alteration of behavior to lethal reactions. The physical environment and physiology of marine fish, however, are different from those of freshwater and estuarine species, and generalizations of results obtained for freshwater/ estuarine species to marine species are therefore not necessarily valid.

The gills are highly exposed to waterborne irritants such as suspended mud particles and may suffer mechanical damage. Fish may adapt to such stress through hypertrophy and hyperplasia of the gill epithelium (Mallat 1985). Stress may activate the hypothalamo-pituitary-interrenal axis and result in release of the steroid cortisol into the bloodstream. Elevated plasma cortisol levels are thus a reliable index of physiological responses to stress (Donaldson 1981).

Atlantic cod Gadus morhua is an important species to the fisheries in the North Atlantic and is commonly caught by bottom trawls. No studies have, however, examined the possible impacts on cod of trawl-resuspended sediment. This paper reports the effects on survival, gill tissue and plasma cortisol levels of experiments that simulate acute $(24 \mathrm{~h})$ and chronic (5 and 10 d) trawl-generated turbidity.

\section{MATERIALS AND METHODS}

Exposure experiments. The experiments were carried out in December 2002. The experimental design consisted of 4 groups each of 10 fish. One of the 4 groups was taken as control. The fish in this group were subjected to clean seawater for $1 \mathrm{~d}$. Fish in the remaining 3 treatment groups were subjected to a fixed concentration of suspended mud for the duration of 1,5 and 10 d respectively. Due to logistic and economic constraints only one experimental tank was available for the experiments and no replicates of the 4 experimental groups could be taken.

An outdoor $18 \mathrm{~m}^{3}$ concrete tank (filled to $15 \mathrm{~m}^{3}$ ) was used for the exposure experiments (Fig. 1). To keep the sediment in suspension and maintain a constant turbid environment, the tank was equipped with 5 circulation pumps. Two pumps (Grundfos KP250, $11.2 \mathrm{~m}^{3} \mathrm{~h}^{-1}$ ) were placed $30 \mathrm{~cm}$ below the surface on each long side of the tank. Another pump was connected to a $53 \mathrm{~mm}$ diameter perforated suction pipe and a non-perforated outflow pipe, both of which were secured to the bottom of the tank. The circulation pumps also ran during the control group experiment. A meter (SAIV STD/CTD model SD204, SAIV AS) that recorded turbidity, temperature, salinity and density was placed $50 \mathrm{~cm}$ below the surface

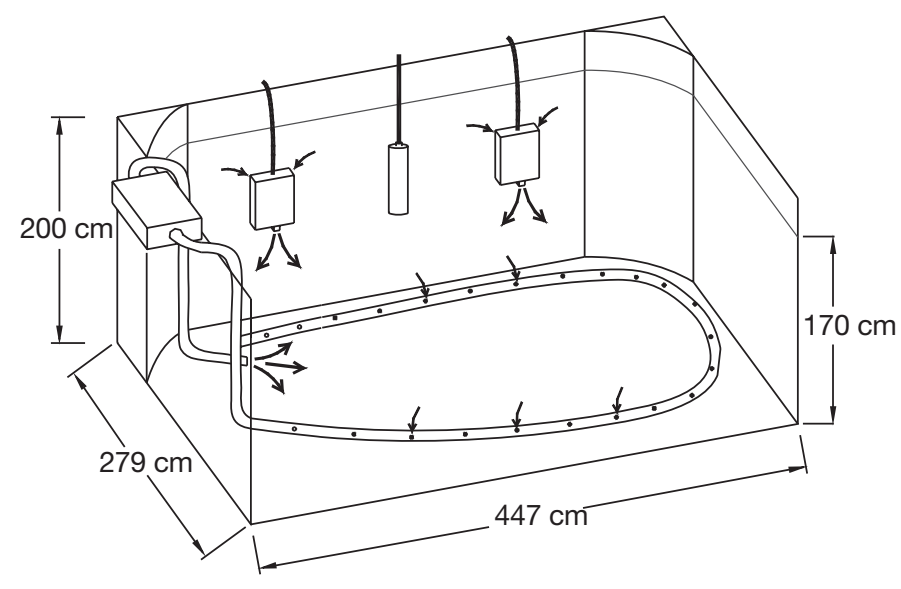

Fig. 1. The $18 \mathrm{~m}^{3}$ concrete outdoor tank used in the experiment (nearest wall and pumps not shown for clarity). Seawater was filled to a depth of $170 \mathrm{~cm}$, giving a volume of $\sim 15 \mathrm{~m}^{3}$. Five pumps were used to create turbulence and prevent the dissolved sediment from settling. Arrows: direction of water flow

in the centre of the tank (Fig. 1). Oxygen saturation was monitored once a day and was stable around $\sim 98 \% \mathrm{O}_{2}$ $\left(9 \mathrm{mg} \mathrm{l}^{-1}\right)$ throughout the experiments.

The order in which the 4 groups were studied was randomized. At the end of each of the 4 experiments the water level in the tank was slowly $(\sim 3 \mathrm{~h})$ lowered to $25 \mathrm{~cm}$ without disturbing the fish, and the 10 fish were collected one by one with a landing net. The tank was then cleaned and water (and suspended mud) completely renewed before the next experiment started with the stocking of the tank by another group of 10 fish. There was no exchange of water during each experiment.

The cod used in the experiments were supplied by the Parisvatnet field station near Bergen in western Norway. Two weeks before the start of the experiments, the cod were moved to a storage tank on the experimental site and acclimatized to the same water supply as used in the experiments (temperature 8 to $9^{\circ} \mathrm{C}$, salinity $34.5 \mathrm{ppt}$ ). The fish were fed until the start of the experiments. The length of the 40 experimental fish was $24.70 \pm 1.58 \mathrm{~cm}$ (mean $\pm \mathrm{SD})$.

Sediment with a mud content of $\sim 47 \%$ (muddy sand [Flemming 2000], hereafter termed mud) (Table 1) was collected with a Smøgen grab at a 150 m deep shrimptrawling ground in a fjord near Bergen. The sediment contained live specimens of crustaceans, ophiuroids and bivalves and neither smell nor colour indicated anoxic conditions. Particle roundness was estimated by visual comparisons of grains with standard images of 6 classes (very angular, angular, subangular, subrounded, rounded, well rounded) of grains with known roundness (Blatt et al. 1972). Our sediments were subjectively classified as angular to subrounded. The dry wt proportion of the mud was $50.2 \pm 0.12 \%$ (mean \pm 
Table 1. Sediment particle size distribution of the muddy sand used in the experiment. $\Phi:-\log _{2}$ (sieve mesh in $\mathrm{mm}$ )

\begin{tabular}{|lccc|}
\hline Sediment & Diameter $(\mathrm{mm})$ & $\Phi$ & $\%$ Mass \\
\hline Very coarse sand & $>1.0$ & $>0$ & 0.9 \\
Coarse sand & $>0.5$ & $>1$ & 3.6 \\
Medium sand & $>0.25$ & $>2$ & 12.8 \\
Fine sand & $>0.125$ & $>3$ & 18.1 \\
Muddy sand & $>0.063$ & $>4$ & 17.3 \\
Coarse silt & $<0.063$ & $<4$ & 47.3 \\
\hline
\end{tabular}

$\mathrm{SE}$ ). The conversion was established by drying 20 samples of wet mud of known weight at $90^{\circ} \mathrm{C}$ until the weight stabilized.

The turbidity meter was calibrated by maintaining known amounts of sediment in suspension in a 501 bucket. The suspended sediment concentrations (SSC) were then plotted against the Formazin Turbidity Unit (FTU) readings on the turbidity meter. The coefficients of the relationship were estimated by a weighted linear regression using the inverse of the variance as weights (Fig. 2):

$$
\mathrm{FTU}=0.217 \cdot \mathrm{SSC}+2.324
$$

At the start of each experiment, mud was dissolved in a bucket and poured into the experimental tank until the desired concentration of $\sim 550 \mathrm{mg} \mathrm{l}^{-1}$ wet wt was read from the turbidity meter $(\sim 120$ FTU). Turbidity was also continuously monitored during the experiments (Fig. 3).

Cortisol analysis. Immediately after capture the fish were killed by a blow to the head and blood samples were taken from the caudal vein with a heparinized syringe, transferred to two $5 \mathrm{ml}$ capillary tubes and centrifuged at $4000 \mathrm{rpm}(1666 \times g)$ for $6 \mathrm{~min}$ to separate plasma and cells. The plasma was then collected into capillary tubes and frozen at $-80^{\circ} \mathrm{C}$. Cortisol was measured by enzyme-linked immunosorbent assay (ELISA,

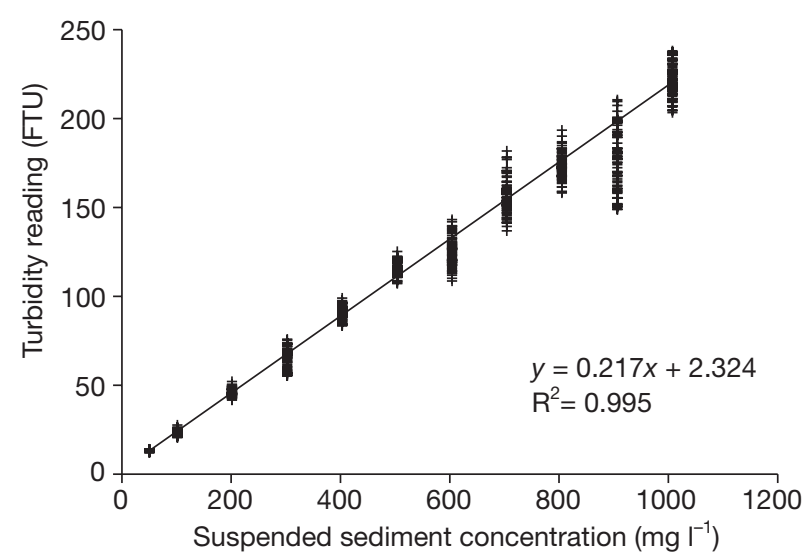

Fig. 2. Calibration curve used to convert turbidity readings (FTU) into suspended sediment concentration $\left(\mathrm{mg} \mathrm{l}^{-1}\right)$

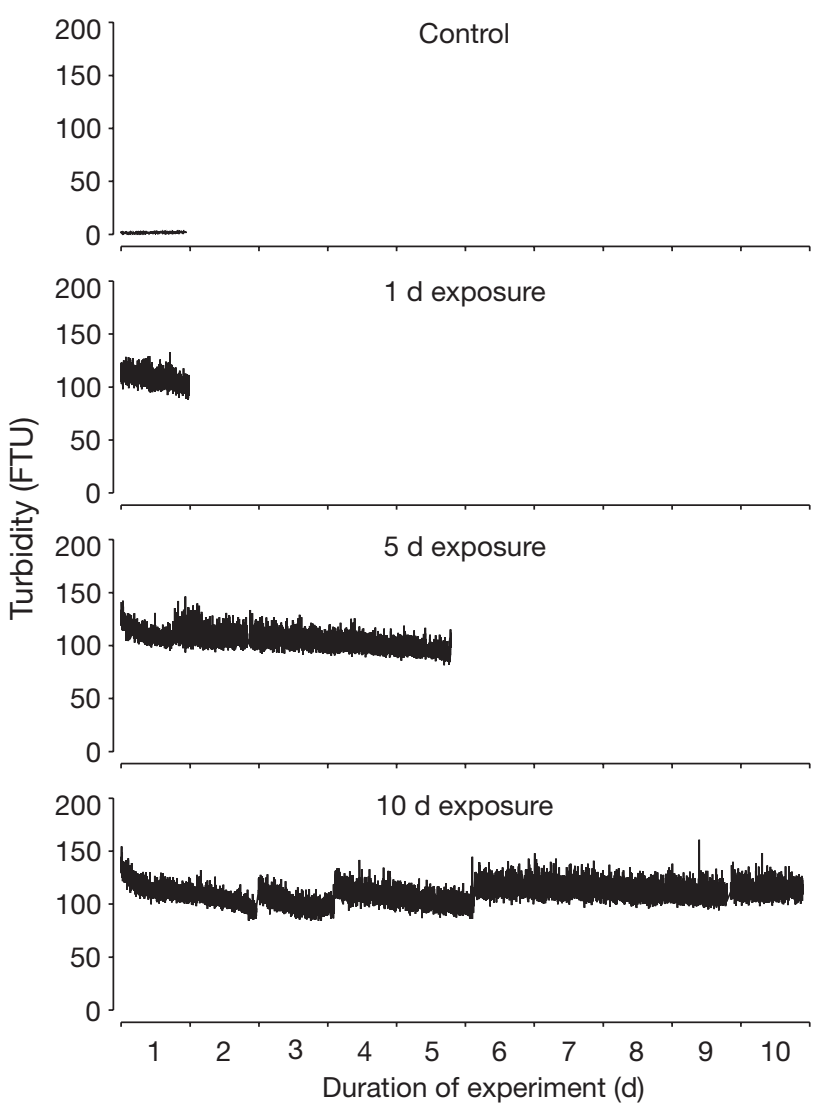

Fig. 3. Recorded temporal variation in measured turbidity during each of the exposure experiments

Barry et al. 1993) modified from a protocol developed by Cayman Chemical using cortisol-horseradish peroxidase conjugate (cortisol linked at the $3 \mathrm{CMO}$ position; Biostride, supplied by East Coast Biologics) as tracer (B. Norberg pers. comm.). Free steroids were extracted from $100 \mu \mathrm{l}$ plasma with diethyl ether and heptane (Hyllner et al. 1994), and after evaporation of the ether the samples were diluted (to fit the standard curve) by adding buffer. The ELISA assay was then run and sample cortisol concentrations were read from the standard curve. The assay was run twice on each fish for cross-validation purposes. Overall differences in cortisol levels between groups were checked for significance $(\alpha=0.05)$ by a robust non-parametric ANOVA (aovRob function; S_Plus 6 Robust Library, Insightful). Pairwise comparisons were made using Wilcoxon rank-sum tests, using Bonferronicorrected significance levels $\left(\alpha^{\prime}=0.008\right)$.

Histological analysis. Following blood sampling, the third gill arch on the left side of each fish was dissected free. Three samples, each containing from 10 to 15 primary lamellae, were cut from the dorsal, middle and ventral parts of each arch. The samples were fixed by immersion in $10 \%$ formalin in neutral phosphate buffer, dehydrated in ethanol and embedded in Tech- 

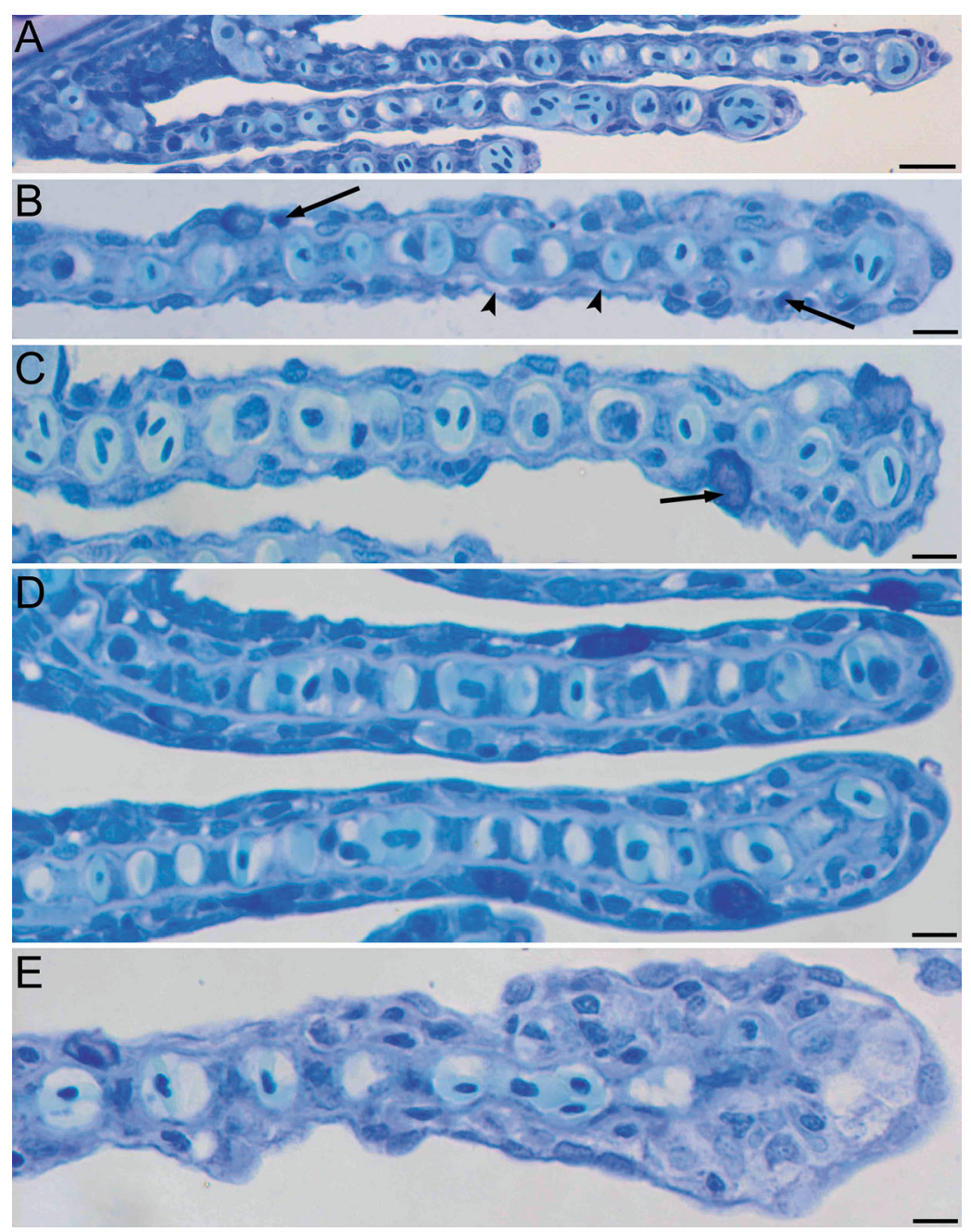

Fig. 4. Gadus morhua. Light micrographs of $4 \mu \mathrm{m}$ sections of methacrylate-embedded gill tissue from Atlantic cod stained with toluidine blue. The images show representative samples. (A) The reference group had a normal gill structure, with a thin squamous epithelium covering the secondary lamellae. Scale bar = $100 \mu \mathrm{m}$. (B) In the $1 \mathrm{~d}$ exposure group an increased thickness of the epithelium, probably due to degeneration in the form of cell swelling, was observed in some regions. Single necrotic cells with dense, dark, pyknotic nuclei were also present within the epithelium (arrows). Moderate focal edema was observed between the epithelium and pillar cells (arrowheads). Scale bar $=50 \mu \mathrm{m}$. (C) In the $5 \mathrm{~d}$ exposure group, hypertrophy of the epithelium was observed on some secondary lamellae. An increased amount of mucous cells was also observed (arrow). Scale bar = $50 \mu \mathrm{m}$. (D) Exposure for $10 \mathrm{~d}$ resulted in more widespread and pronounced hypertrophy and hyperplasia of the gill epithelium compared to the $5 \mathrm{~d}$ exposure group. Note the 2-layered cuboid epithelium with mucous cells on secondary lamellae. Scale bar $=50 \mu \mathrm{m}$. (E) Secondary lamella with apical hyperplasia from the $10 \mathrm{~d}$ exposure group. Scale bar $=50 \mu \mathrm{m}$ novit 7100 (Heraeus Kulzer). Cross-sections (4 $\mu \mathrm{m}$ thick) of the middle portion of the secondary lamellae were then cut, mounted on glass slides and stained with toluidine blue (Philpott 1966). Digital micrographs were acquired using a ProgRes C14 camera (Jenoptik) on an Olympus Vanox AHBT3 microscope, and the images were processed using Adobe Photoshop.

\section{RESULTS}

All fish survived the experiments with neither external gross pathological lesions nor changes in behaviour. Macroscopically, the gills of fish from the different groups were similar, and no marked accumulation of mucus was observed, after either 5 or $10 \mathrm{~d}$ of exposure. Histological examination showed that there were no apparent differences between samples taken from the dorsal, middle or ventral region of the gill arch in any group. Within each group, the characteristics of the gill tissue showed low variation and were similar in all individuals. All the fish of the reference group had normal gill tissue were the pillar cells of the secondary lamellae were covered with a squamous epithelium, with a moderate amount of mucous cells at the bases of the secondary lamellae and along the primary lamellae (Fig. 4A). In the $1 \mathrm{~d}$ exposure group, all fish had gill tissue lesions that showed a multifocal distribution and affected ca. $30 \%$ of the secondary lamellae. The lesions were characterized by degeneration of the gill epithelium where the cells appeared swollen and by sparse subepithelial edema, extending the intercellular space between the epithelium and pillar cells (Fig. 4B). Furthermore, single-cell necrosis with pyknosis was sometimes observed within the lesions. In all fish of the $5 \mathrm{~d}$ exposure group, a marked hypertrophy of the gill epithelium was evident, affecting ca. $70 \%$ of the secondary lamellae (Fig. 4C). The epithelium showed a cuboid morphology with moderate increase in the number of mucous cells. After $10 \mathrm{~d}$ of exposure, hyperplasia within the epithelium had occurred in all fish, and more than $80 \%$ of the secondary lamellae had 
a single or a double layer of cuboid epithelial cells (Fig. 4D). In this group, the apices of the secondary lamellae displayed the most severe epithelial hypertrophy and hyperplasia (Fig. 4E). No subepithelial haematomas (thelangiectasis) were observed.

Individual cortisol responses were highly variable within each group, especially in the $10 \mathrm{~d}$ exposure group (Fig. 5). In the reference group one outlier was observed. There was an overall difference in cortisol level between the experimental groups (Robust non-parametric ANOVA, $p<0.001$ ). Pairwise comparisons of the groups showed significantly higher cortisol level in the $5 \mathrm{~d}$ exposure group than in the $1 \mathrm{~d}$ exposure group (Table 2 \& Fig. 5). None of the other group comparisons were significant at the Bonferroni-adjusted p-levels.

\section{DISCUSSION}

The exposure of cod to suspended mud concentrations of $550 \mathrm{mg} \mathrm{l}^{-1}$ for periods ranging from $24 \mathrm{~h}$ to $10 \mathrm{~d}$ resulted in no mortality. Lethal effects of $24 \mathrm{~h}$ exposure

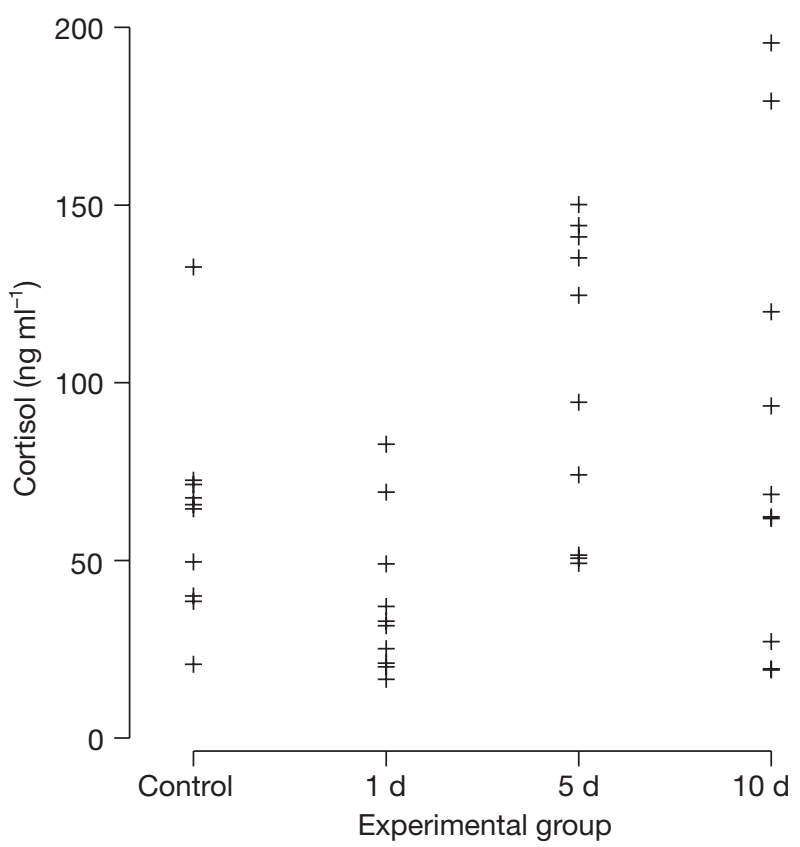

Fig. 5. Gadus morhua. Measured cortisol levels for each of the 10 fish in the 4 experimental groups

Table 2. Gadus morhua. Pairwise comparisons of the cortisol levels of the 4 experimental groups using a Wilcoxon rank sum test. *Significant at Bonferroni-adjusted p-level

\begin{tabular}{|lccc|}
\hline & $1 \mathrm{~d}$ & $5 \mathrm{~d}$ & $10 \mathrm{~d}$ \\
\hline Control & 0.0524 & 0.0355 & 0.7959 \\
$1 \mathrm{~d}$ & - & $0.0005^{*}$ & 0.1431 \\
$5 \mathrm{~d}$ & - & - & 0.3930 \\
\hline
\end{tabular}

of Atlantic silverside were observed for concentrations as low as $58 \mathrm{mg} \mathrm{l}^{-1}$, while at the other extreme mummichogs survived a $24 \mathrm{~h}$ exposure to concentrations as high as $300000 \mathrm{mg} \mathrm{l}^{-1}$ (Newcombe \& Jensen 1996). A wide range of tolerance levels is to be expected as some fish normally inhabit turbid waters (e.g. estuarine and riverine species) while others spend their entire life in clear oceanic water (e.g. marine pelagic species). Bottom-dwelling species may also be tolerant to high suspended sediment loads, e.g. burrowing flatfish and sand eels and fish feeding on epi- and infauna (e.g. haddock). The presence of a zone of high turbidity near the bottom (nepheloid zone) forced by tides, currents, waves and bioturbation (Cacchione \& Drake 1986, Graf \& Rosenberg 1997, Pilskaln et al. 1998, Palanques et al. 2001) may have adapted fish to elevated suspensoid loads, but under such conditions concentrations will usually be much lower than those recorded immediately after trawling. Models have been developed for assessing ill-effects related to sediment doses for lotic, lentic and estuarine species (Newcombe \& MacDonald 1991, Newcombe \& Jensen 1996, Newcombe 2003). However, the predicted responses had a poor fit to the responses registered in our data. The general paucity of data for marine bottom-dwelling species as a background for these studies probably reflects the lack of recognition of trawlgenerated resuspension of sediment as a potentially important and large-scale phenomenon.

Sediment particle size used in our experiment was relatively small. Small particles caused fewer deleterious effects to salmonids than larger particles (Servizi \& Martens 1987). However, the particle size used is similar to that found in large areas of the Barents Sea (Elverhøi \& Solheim 1983).

Our sediment particle form was classified as subangular to rounded. Angular particles may place fish under stress at lower concentrations than rounded particles, but no difference between sediment particle shapes in causing mortality was observed at any sediment concentration (Lake \& Hinch 1999). Data on typical particle shape of the sediments in the trawled areas of the Barents Sea are lacking, but by using relatively angular particles the chance of detecting potential harmful effects is increased.

The experimental fish were exposed to constant suspended mud concentrations of $550 \mathrm{mg} \mathrm{l}^{-1}$ for periods up to $10 \mathrm{~d}$. The response of fish to suspended sediments is mainly a function of duration and concentration (dose) (Newcombe \& MacDonald 1991). Given the lack of a reference point for sediment concentration and extinction rates representative of commercial fishing, our experiment was designed to mimic the highest concentrations referenced behind trawls (Schubel et al. 1979) in order to create a 
worst-case scenario. Concentrations may be expected to fall rapidly due to settling of large and flocculated particles (Durrieu de Madron et al. 2005). However, approx. $1 / 10$ to $1 / 3$ of the initial load may remain in suspension for several days (Palanques et al. 2001, Durrieu de Madron et al. 2005), depending on sediment grain size and currents in the area, creating and sustaining the bottom nepheloid layer (Pilskaln et al. 1998). Most studies have been concerned with assessing single-passage characteristics and plume dimensions experimentally (e.g. Main \& Sangster 1981, Palanques et al. 2001), while only a few have tried to quantify and compare the magnitude of trawling-resuspended sediment on the scale of commercial fisheries with that of natural resuspension or turbidity (but see Churchill 1989, Floderus \& Pihl 1990, Pilskaln et al. 1998). As opposed to wind-generated resuspension, trawl-generated resuspension often lacks a simultaneous association with strong current action (Churchill 1989). Extinction rates are therefore more dependent on gravity, and in areas of high mud content and low currents trawling may become the main agent of resuspension. The geographical distribution of fishing vessels is patchy and likely to follow the densest fish aggregations. Fishing effort may therefore in certain areas be high and produce continuous contributions to suspended sediments, possibly producing semichronic turbid situations like the one simulated by our $10 \mathrm{~d}$ exposure experiment.

The gill lesions observed in our study were similar to those observed in other species after exposure to similar irritants (Mallat 1985). The multifocal degenerative lesions observed after $1 \mathrm{~d}$ of exposure are typical acute pathological changes. Although the lesions were moderate, they may have impaired epithelial barrier functions and induced osmoregulatory dysfunction. After $5 \mathrm{~d}$ of exposure, adaptive changes, in the form of hypertrophy and moderate hyperplasia of the gill epithelium, had taken place. These responses, including hyperplasia of mucous cells, were more marked and widespread after $10 \mathrm{~d}$ of exposure. When compared with the extent of lamellar hyperplasia described in other species (Roberts 2001, Mallat 1985), the changes observed in the present study may be described as moderate. The impact of severe lamellar hyperplasia on respiration has been studied in Atlantic salmon, in which no effect on exercise tolerance could be observed, probably due to the large respiratory reserve capacity of the gills (Errard \& Ross 1987). The moderate chronic lesions observed on the cod in the present study, therefore, probably had only an insignificant negative effect on respiration, excretion and osmoregulation. A build-up of a thick mucus layer on the gills could have further impeded respiration, but this was not evident in the present study. Complete recovery from both epithelial degenerative oedematous lesions and from lamellar hyperplasia has been reported to occur in other species within one to a few weeks after the irritants are no longer present in the water (Fukuda 1983, Goldes et al. 1988).

The cortisol levels found in our reference group (median $=65.1 \mathrm{ng} \mathrm{l}^{-1}$ ) were similar to those of Audet et al. (1993) but higher than those obtained by Morgan et al. (1999), both studies referring to cod. On the other hand, our reference level has been taken as indicative of stress in other studies on cod (Dutil et al. 1992, Staurnes et al. 1994a,b). Exposure to low temperature as a stressor has been shown to result in wide variations in plasma cortisol values in cod (Staurnes 1994a). The highly variable cortisol measurements within groups are thus likely to resemble normal individual variation in stress tolerance, except for the outlier in the reference group which may have had an undetected infection or lesion. An interpretation of the variance in cortisol reference levels is that the lowest values are indicative of unstressed fish and that higher levels are indicative of some degree of stress associated with husbandry or sampling procedures (Pankhurst \& Sharples 1992).

The time spent collecting a fish with a landing net and preparing for the blood sampling took in all cases less than $5 \mathrm{~min}$. Cortisol values may increase within minutes of handling (Pankhurst \& Sharples 1992), but there are marked species differences. The severity of stressors may also have an effect on the rate of increase of plasma cortisol levels (Pickering \& Pottinger 1987). Pankhurst \& Sharples (1992) showed a $1 \mathrm{~h}$ latency in response in snapper Pagrus auratus after underwater confinement, a slower response than has been reported in blue mao mao Scorpis violaceus, red drum Scianops ocellatus, rainbow trout Salmo gairdneri and coho salmon Oncorhynchus kisutch after exposure to a variety of stressors (references cited in Pankhurst \& Sharples 1992). Cod exposed to handling and transport reached a cortisol maximum half an hour after handling and transport (Hemre et al. 1991). Assuming the slow emptying of the experimental tank did not stress the fish, the comparatively short handling time in the present study is not likely to constitute a major source of bias in the observed cortisol levels.

Based on the similarity of cortisol levels in the control and $1 \mathrm{~d}$ exposure groups, the environmental change going from clear to turbid water did not produce a stress reaction. The acute lesions observed after $1 \mathrm{~d}$ may have become more severe and widespread after longer exposure times and peaked somewhere between 1 and $5 \mathrm{~d}$, leading to the increased cortisol values measured after $5 \mathrm{~d}$. It is suggested that 
the lower cortisol values for some fish in the $10 \mathrm{~d}$ exposure group as compared to fish in the $5 \mathrm{~d}$ exposure group reflect stress reduction as fish physiologically adapt to the turbid environment, as shown by the histological analysis.

\section{CONCLUSION}

No mortality was observed as a result of exposure of cod to suspended sediment. However, acute and chronic gill lesions were observed as well as a general stress response as revealed by plasma cortisol levels. Both of these were evaluated as moderate responses that would be reversible if the fish were given time to recover in an uncontaminated environment. Wild cod may also evade suspended mud clouds by horizontal or vertical migration. Given the short time envelope and high concentration of suspended material, our results suggest that cod should suffer only sublethal reactions to turbidity generated by trawling in isolation. However, other stressful effects of trawling such as herding, swimming to exhaustion, crowding, predator avoidance, and contact with gear and selection devices may interact with and add to the overall stress response and result in mortality (Barton et al. 1986, Barton \& Iwama 1991, Davis 2002, Ryer 2003). Cod is a robust species, and the results for this species are not necessarily applicable to other, less tolerant, species. Data on the responses of other species are therefore needed, as well as studies of potential stressor interactions during the capture process.

Acknowledgements. The authors thank M. Fonn for preparing the histological sections, B. Norberg and her team for performing the cortisol analyses, O. S. Kjesbu for providing the experimental fish and arranging access to the laboratory and tank facilities, A.-B. Skar Tysseland for drawing Fig. 1, G. Tveit for sediment analyses, T. Sigholt and J. Morgan for interpretation of the cortisol data and J. H. Churchill for literature on trawl-resuspended sediment. We also acknowledge the financial support of the Research Council of Norway.

\section{LITERATURE CITED}

Audet C, Besner M, Munro J, Dutil JD (1993) Seasonal and diel variations of various blood parameters in Atlantic cod (Gadus morhua) and American plaice (Hippoglossoides platessoides). Can J Zool 71:611-618

Barton BA, Schreck CB, Sigismondi LA (1986) Multiple acute disturbances evoke cumulative physiological stress responses in juvenile Chinook salmon. Trans Am Fish Soc 115:245-251

Barton BA, Iwama GK (1991) Physiological changes in fish from stress in aquaculture with emphasis on the response and effects of corticosteroids. Annu Rev Fish Dis 1:3-26

Barry TP, Lapp AF, Kayes TB, Malison JA (1993) Validation of a microtitre plate ELISA for measuring cortisol in fish and comparison of stress responses of rainbow-trout (Oncorhyncus mykiss) and lake trout (Salvelinus namaycush). Aquaculture 117(3-4):351-363

Bruton MN (1985) The effects of suspensoids on fish. Hydrobiologia 125:221-241

Cacchione DA, Drake DE (1986) Nephloid layers and internal waves over continental shelves and slopes. Geo-Mar Lett 6:147-152

Churchill JH (1989) The effect of commercial trawling on sediment resuspension and transport over the Middle Atlantic Bight continental shelf. Cont Shelf Res 9(9):841-864

Collie JS, Hall SJ, Kaiser MJ, Pointer IR (2000) A quantitative analysis of fishing impacts on shelf-sea benthos. J Anim Ecol 69:785-799

Davis MW (2002) Key principles for understanding fish bycatch discard mortality. Can J Fish Aquat Sci 59: $1834-1843$

Dayton PK, Thrush SH, Agardy MT, Hofman RJ (1995) Environmental effects of marine fishing. Aquat Conserv Mar Freshw Ecosyst 5(3):205-232

Donaldson EM (1981) The pituitary-interrenal axis as an indicator of stress in fish. In: Pickering AD (ed) Stress and fish. Academic Press, London, p 11-47

Duplisea DE, Jennings S, Malcolm SJ, Parker R, Sivyer D (2002) Modelling the potential impact of bottom trawl fisheries on soft sediment biochemistry in the North Sea. Geochem Trans 14:1-6

Durrieu de Madron X, Ferré B, Le Corre G, Grenz C, Conan P, Pujo-Pay M, Buscail R, Bodiot O (2005) Trawlinginduced resuspension aand dispersal of muddy sediments and dissolved elements in the Gulf of Lion (NW Mediterranean). Contin Shelf Res 25:2387-2409

Dutil JD, Munro J, Audet C, Besner M (1992) Seasonal variation in the physiological response of Atlantic cod (Gadus morhua) to low salinity. Can J Fish Aquat Sci 49: $1149-1156$

Elverhøi A, Solheim A (1983) The physical environment, Western Barents Sea; surface sediment distribution. Norsk Polarinstitutt Skrifter 179A

Errard C, Ross LG (1987) Studies of glochidiosis of salmon. Annual report. Institute of Aquaculture, University of Sterling, p 17-19

Flemming BW (2000) A revised textural classification of gravel-free muddy sediments on the basis of ternary diagrams. Contin Shelf Res 20:1125-1137

Floderus S, Pihl L (1990) Resuspension in the Kattegat: impact of variation in wind climate and fishery. Estuar Coast Shelf Sci 31:487-498

Folmar LC (1993) Effects of chemical contaminants on blood chemistry of teleost fish: a bibliography and synopsis of selected effects. Environ Toxicol Chem 12:337-375

Fukuda Y (1983) Specific reactions of goldfish gills exposed to linear alkylbenzenesulphonate. Jpn J Ichthyol 30:268-274

Goldes SA, Ferguson HW, Moccia RD, Daoust PY (1988) Histological effects of the inert suspended clay caolin on the gills of juvenile rainbow trout, Salmo gairdneri Richardson. J Fish Dis 11:23-34

Graf G, Rosenberg R (1997) Bioresuspension and biodeposition: a review. J Mar Syst 11:269-278

Hemre GI, Lambertsen G, Lie Ø (1991) The effect of dietary carbohydrate on the stress response in cod (Gadus morhua). Aquaculture 95:319-328

Hyllner SJ, Norberg B, Haux C (1994) Isolation, partial characterization, induction, and the occurrence in plasma of the major vitelline envelope proteins in the Atlantic halibut (Hippoglossus hippoglossus) during sexual maturation. Can J Fish Aquat Sci 51(8):1700-1707 
Jennings S, Kaiser M (1998) The effects of fishing on marine ecosystems. Adv Mar Biol 34:201-352

Jones JB (1992) Environmental impact of trawling on the seabed: a review. N Z J Mar Freshwat Res 26(1):59-67

Kaiser MJ, Collie JS, Hall SJ, Jennings S, Pointer IR (2002) Modifications of marine habitats by trawling activities: prognosis and solutions. Fish Fish 3:114-136

Lake RG, Hinch SG (1999) Acute effects of suspended sediment angularity on juvenile coho salmon (Oncorhynchus kisutsch). Can J Fish Aquat Sci 56:862-867

Main J, Sangster GI (1981) A study of sand clouds produced by trawl boards and their possible effect on fish capture. Scott Fish Res Rep No. 20

Mallat J (1985) Fish gill structural changes induced by toxicants and other irritants: a statistical review. Can J Fish Aquat Sci 42:630-648

Morgan MJ, Wilson CE, Crim LW (1999) The effect of stress on reproduction in Atlantic cod. J Fish Biol 54:477-488

Newcombe CP (2003) Impact assessment model for clear water fishes exposed to excessively cloudy water. J Am Water Resour Assoc 39(3):529-544

Newcombe CP, Jensen JOT (1996) Channel suspended sediment and fisheries: a synthesis for quantitative assessment of risk and impact. North Am J Fish Manage 16:693-727

Newcombe CP, MacDonald DD (1991) Effects of suspended sediments on aquatic ecosystems. North Am J Fish Manage 11:72-82

Palanques A, Guillén J, Puig P (2001) Impact of bottom trawling on water turbidity and muddy sediment of an unfished continental shelf. Limnol Oceanogr 46(5):1100-1110

Pankhurst NW, Sharples DF (1992) Effects of capture and confinement on plasma cortisol concentrations in the snapper (Pagrus auratus). Aust J Mar Freshw Res 43:345-356

Philpott DE (1966) A rapid method for staining plastic-embedded tissues for light microscope. Sci Instrum 11:11-12

Pickering AD, Pottinger TG (1987) Poor water quality suppresses the cortisol response of salmonid fish to handling and confinement. J Fish Biol 30:363-374

Pilskaln CH, Churchill JH, Mayer LM (1998) Resuspension of sediment by bottom trawling in the Gulf of Maine, and potential geochemical consequences. Conserv Biol 12(6): 1223-1229

Editorial responsibility: Otto Kinne (Editor-in-Chief), Oldendorf/Luhe, Germany
Roberts RJ (2001) Fish pathology, 3rd edn. Saunders, Philadelphia, PA

Ryer CH (2003) Trawl stress and escape vulnerability to predation in juvenile walleye pollock: Is there an unobserved bycatch of behaviourally impaired escapees? Mar Ecol Prog Ser 232:269-279

Schoellhamer DH (1996) Anthropogenic sediment resuspension mechanisms in a shallow microtidal estuary. Estuar Coast Shelf Sci 43:533-548

Schubel JR, Carter HH, Wise WM (1979) Shrimping as a source of suspended sediment in Corpus Christi Bay (Texas). Estuaries 2(3):201-203

Schwinghamer P, Gordon DC, Rowell TW, Prena J, McKeown DL, Sonnichsen G, Guigné JY (1998) Effects of experimental otter trawling on surficial sediment properties of a sandy-bottom ecosystem on the Grand Banks of Newfoundland. Conserv Biol 12(6):1215-1222

Servizi JA, Martens DW (1987) Some effects of suspended Fraser River sediments on sockeye salmon, Oncorhyncus nerka. In: Smith HD, Margolis L, Wood CC (eds) Sockeye salmon, Oncorhyncus nerka, population biology and future management. Can Spec Publ Fish Aquat Sci 96: 254-264

Smith CJ, Papadopoulou KN, Diliberto S (2000) Impact of otter trawling on an eastern Mediterranean commercial trawl fishing ground. ICES J Mar Sci 57:1340-1351

Staurnes M, Rainuzzo JR, Sigholt T, Jørgensen L (1994a) Acclimation of Atlantic cod (Gadus morhua) to cold water: stress response, osmoregulation, gill lipid composistion and gill NA-K-ATPase activity. Comp Biochem Physiol 109A(2):413-421

Staurnes M, Sigholt T, Pedersen HP, Rustad T (1994b) Physiological effects of simulated high-density transport of Atlantic cod (Gadus morhua). Aquaculture 119:381-391

Wardle CS (1983) Fish reactions to towed fishing gears. In: MacDonald AG, Priede IG (eds) Experimental biology at sea. Academic Press, London, p167-195

Wilber DH, Clarke DG (2001) Biological effects of suspended sediments: a review of suspended sediment impacts on fish and shellfish with relation to dredging activities in eastuaries. North Am J Fish Manage 21: 855-875

Submitted: March 4, 2005; Accepted: September 2, 2005 Proofs received from author(s): February 2, 2006 